\title{
Retinol Binding Protein dan Luaran Pascabedah
}

\author{
Sri Martuti, ${ }^{* *}$ Antonius Pudjiadi, ${ }^{*}$ Abdul Latief, ${ }^{*}$ Yusrina Istanti, ${ }^{* * *}$ Pudjiastuti, ${ }^{* *}$ \\ Moh. Supriatna ${ }^{* * *}$ \\ *Departemen Ilmu Kesehatan Anak Fakultas Kedokteran Universitas Indonesia/RS Cipto Mangunkusumo, \\ Jakarta, "Bagian Ilmu Kesehatan Anak Fakultas Kedokteran Universitas Sebelas Maret /RSUD Dr. \\ Moewardi, Surakarta, "' Departemen Ilmu Kesehatan Anak Fakultas Kedokteran Universitas Diponegoro/ \\ RSUP Dr. Kariadi, Semarang
}

\begin{abstract}
Latar belakang. Malnutrisi sering ditemukan pada pascabedah dan berhubungan dengan luaran yang tidak baik, seperti sepsis atau infeksi luka operasi. Retinol binding protein (RBP) merupakan parameter biokimia yang cukup reliabel untuk menilai malnutrisi.

Tujuan. Mengetahui pengaruh malnutrisi berdasarkan penurunan RBP terhadap luaran pasien pascabedah

Metode. Penelitian observasional analitik dilakukan di ICU Anak tiga rumah sakit yakni RS Cipto Mangunkusumo, RSUP Dr. Kariadi, dan RSUD Dr. Moewardi. Dilakukan pengukuran RBP, kortisol, CRP pada hari pertama dan kelima pascabedah. Luaran infeksi dinilai berdasarkan skor ASEPSIS. Analisis bivariat dilakukan terhadap beberapa faktor risiko dengan kejadian infeksi luka operasi dan sepsis. Analisis data menggunakan program SPSS versi 17.00 .

Hasil. Selama kurun waktu 6 bulan, 39 subjek memenuhi kriteria inklusi, tetapi 4 tidak melanjutkan penelitian. Penurunan kadar RBP hari kelima pascabedah 34,3\% kasus. Penurunan RBP, CRP, usia $<1$ tahun, dan skor ASA $\geq 3$ berisiko mendapatkan infeksi luka operasi berturut-turut 4,4; 3,3;1,2; dan 1,3 kali dengan nilai $p>0,05$ dan 95\% IK masing-masing (0,35-54,4; 0,3 - 40,8;0,1-15,8; dan 0,97-1,6). Faktor lain-status nutrisi prabedah, lama pembedahan, kategori luka operasi dan kortisol-juga didapatkan hasil yang tidak signifikan. Penelitian ini tidak mendapatkan luaran sepsis.

Kesimpulan. Terdapat risiko terjadi infeksi luka operasi 4,4 kali apabila kadar RBP menurun, 3,3 kali apabila CRP meningkat, 1,2 kali apabila usia $<1$ tahun, dan 1,3 kali apabila skor ASA $\geq 3$, tetapi secara statistik tidak ada perbedaan bermakna. Sari Pediatri 2014;16(4):271-7.
\end{abstract}

Kata kunci: malnutrisi, luaran pascabedah, retinol binding protein

\footnotetext{
Alamat korespondensi:

Dr. Sri Martuti, SpA. Bagian IKA FK-UNS/RS Dr. Moewardi. Jl. Kol. Sutarto 132, Surakarta 57125. No telp. +62271-666866. Email: sri_martuti@idai.or.id
}

I nsiden malnutrisi di rumah sakit masih cukup tinggi. Penelitian di New Zealand didapatkan malnutrisi $52 \%$ pada pasien pembedahan akut dan $38 \%$ pada pembedahan elektif. ${ }^{1}$ Penelitian di Indonesia, oleh Haryanti $\mathrm{dkk}^{2}$ pada pasien pascabedah 
abdomen di RS Cipto Mangunkusumo didapatkan prevalensi gizi kurang 37,8\% dan gizi buruk 3,3\%. Kondisi malnutrisi sering tidak terdiagnosis, sementara malnutrisi terbukti berhubungan dengan peningkatan mortalitas dan morbiditas. Identifikasi malnutrisi lebih dini akan memperbaiki luaran dan diharapkan akan menurunkan biaya selama perawatan. ${ }^{3}$

Retinol binding protein merupakan salah satu indikator nutrisi yang cukup dapat diandalkan (reliable). Prealbumin dan RBP memiliki waktu paruh yang pendek dan terbukti cukup sensitif untuk indikator malnutrisi akut. Retinol binding protein terbukti berkorelasi signifikan dengan prealbumin dan waktu paruh RBP lebih pendek dibandingkan prealbumin. ${ }^{4-6}$

Pada pembedahan mayor, terjadi respons fase akut yang ditandai dengan perubahan pada neuro-endokrin, metabolik, dan respons inflamasi yang ditujukan untuk kelangsungan hidup dengan cara memobilisasi substrat, membatasi kerusakan jaringan, membunuh organisme yang menimbulkan infeksi, dan mengaktivasi proses penyembuhan..$^{7-10}$ Peningkatan kortisol maupun sitokin proinflamasi akan merangsang peningkatan produksi protein fase akut positif dan menurunkan produksi protein fase akut negatif. Protein fase akut positif memiliki fungsi, antara lain untuk opsonisasi dan menghilangkan mikro-organisme dan produknya, aktivasi komplemen, modulasi respons imun host. ${ }^{9}$ Pada pembedahan, C-reactive protein adalah salah satu positif protein fase akut utama, juga merupakan parameter yang dapat menunjukkan derajat inflamasi dan bersama dengan IL-6 digunakan sebagai prediktor komplikasi pascabedah. ${ }^{11}$

Komplikasi pascabedah dipengaruhi oleh status nutrisi prabedah operasi maupun status nutrisi pascabedah. Malnutrisi berhubungan dengan komplikasi penyembuhan luka pada pasien pascabedah. Namun, penelitian tersebut belum mempertimbangkan pengaruh derajat inflamasi yang diwakili oleh CRP secara bersamaan. ${ }^{1,12,13}$ Faktor lain yang berhubungan dengan infeksi luka operasi adalah skor American Society of Anaesthesiology (ASA) 3-5, luka operasi terkontaminasi/terinfeksi, lama operasi, usia dan jenis operasi-usia muda atau terlalu tua akan meningkatkan risiko infeksi. ${ }^{14}$

Di Indonesia, penelitian RBP mengenai angka kejadian malnutrisi dengan menggunakan indikator deteksi malnutrisi akut yang sensitif belum pernah dilakukan. Untuk itu, peneliti ingin mendapatkan angka kejadian malnutrisi pada pembedahan mayor berdasarkan perubahan RBP dan melakukan analisis pengaruh malnutrisi dan faktor lain terhadap luaran pascabedah. Hasil penelitian ini diharapkan dapat digunakan sebagai acuan dalam tatalaksana pasien pascabedah selanjutnya.

\section{Metode}

Penelitian observasional analitik yang dimulai Januari 2014 sampai dengan Juni 2014. Didapatkan 39 subjek penelitian yang memenuhi kriteria inklusi. Empat subjek tidak melanjutkan penelitian (dropout) karena sebelum pengambilan darah hari ke-5, 2 dipulangkan, dan 2 meninggal.

Penelitian dilaksanakan di ruang rawat intensif anak (Pediatric Intensive Care Unit/PICU) dan bangsal rawat bedah RS Cipto Mangunkusumo (RSCM) Jakarta, RSUP Dr. Kariadi Semarang, dan RSUD Dr. Moewardi Surakarta. Populasi target adalah pasien anak pascabedah. Subjek yang diikutsertakan adalah pasien usia 1 bulan sampai dengan 18 tahun, mengalami pembedahan mayor, dan orangtua menandatangani persetujuan mengikuti penelitian. Subjek dikeluarkan dari penelitian apabila mengalami sepsis sebelum pembedahan berdasarkan catatan medis dan mengalami disfungsi hati berat (apabila kadar ALT $>2 \mathrm{x}$ nilai normal berdasar usia). Pemilihan sampel dilakukan secara konsekutif.

Pemeriksaan darah dilakukan pada hari pertama pascabedah, maksimal 24 jam dari pengirisan luka operasi, dan pada hari kelima pascabedah. Pemeriksaan darah meliputi RBP, CRP, dan kortisol dilakukan di laboratorium. Kadar CRP dinyatakan dalam satuan $\mathrm{mg} / \mathrm{L}$, diperiksa dengan cara enzyme linked immunoassay (ELISA). Kadar kortisol dinyatakan dalam satuan $\mu \mathrm{g} / \mathrm{dL}$. Penilaian status nutrisi prabedah berdasarkan pengukuran antropometri berat dan tinggi badan. Penentuan malnutrisi berdasarkan kurva CDC 2000. Penilaian malnutrisi pascabedah berdasarkan perbandingan pengukuran RBP hari pertama dan kelima pascabedah, malnutrisi apabila RBP menurun. Infeksi daerah operasi dinilai berdasarkan skor ASEPSIS, dinyatakan infeksi apabila skor $\geq 20$. Skor ASEPSIS dinilai dalam 5 dari 7 hari pengamatan diambil skor tertinggi. Luka operasi yang telibat diukur dengan pita pengukur dalam 3 kali pengukuran oleh satu orang pengamat di tiap RS dan difoto. Penilaian dilakukan dengan cara panjang luka yang terlibat 
dibagi dengan panjang keseluruhan, hasil dalam persen. Hasil pengukuran diambil dari nilai rata-rata ketiga pengukuran, kemudian dilakukan skoring. Kondisi fisik pasien yang berisiko infeksi apabila skor ASA $\geq 3$. Durasi operasi adalah saat dimulai insisi sampai ditutup kembali, durasi operasi $>2$ jam merupakan risiko infeksi. Jenis luka operasi berdasarkan the National Research Council, terdiri atas kelas 1-4 (1. luka bersih, 2. bersih tercemar, 3. tercemar, 4. kotor). Risiko infeksi bila jenis luka operasi 3-4.

Data yang terkumpul dianalisis menggunakan Pr ogram SPSS versi 17.0 Metode uji chi-square digunakan untuk analisis bivariat. Apabila syarat tidak terpenuhi, digunakan metode uji Fisher's exact. Apabila didapatkan hasil yang bermakna dilanjutkan dengan analisis multivariat. Nilai $\mathrm{p}<0,05$ dianggap secara statistik bermakna. Data dinyatakan dalam persentase, rerata, simpang baku, Rasio Odds, dan 95\% interval kepercayaan. Persetujuan etik oleh Komite Etik Penelitian Fakultas Kedokteran Universitas Indonesia tanggal 4 November 2013 dengan nomor 685/H2.F1/ ETIK/2013.

\section{Hasil}

Sebagian besar subjek (60\%) berjenis kelamin lakilaki. Kelompok usia terbanyak (25 subjek) adalah kurang dari 1 tahun, status gizi prabedah (40\%) didapatkan gizi kurang. Skor ASA terbanyak adalah skor $2(57,1 \%)$, jenis luka tercemar atau terinfeksi tidak ditemukan. Jenis operasi paling banyak adalah neurosurgery $(54,4 \%)$. Secara lengkap karakteristik subjek tertera pada Tabel 1.

Retinol binding protein untuk parameter malnutrisi didapatkan menurun pada 34,3\% kasus. Parameter inflamasi, peningkatan kortisol, dan CRP didapatkan berturut-turut pada $42,9 \%$ dan $40 \%$ kasus. Tidak didapatkan luaran sepsis, sedangkan luaran infeksi pada luka operasi didapatkan $3(8,6 \%)$.

Kadar kortisol, RBP, dan CRP pada hari pertama dan kelima pascabedah tertera pada Tabel 2. Terdapat peningkatan rerata kadar RBP dan CRP pada hari pertama pascabedah dibandingkan hari kelima pascabedah, sedangkan kortisol serum didapatkan menurun.

Analisis bivariat beberapa faktor risiko infeksi luka operasi tertera pada Tabel 3. Faktor usia didapatkan hasil subjek dengan usia $<1$ tahun berisiko mendapatkan infeksi luka operasi 1,2 kali dibandingkan subjek dengan usia 1 tahun atau lebih $(\mathrm{p}=0,64 ; 95 \%$ IK $0,10,1-15,8)$. Penurunan kadar RBP pada hari ke-5

Tabel 1. Karakteristik subjek penelitian $(\mathrm{n}=35)$

\begin{tabular}{|c|c|}
\hline Karakteristik & Jumlah n (\%) \\
\hline \multicolumn{2}{|l|}{ Jenis kelamin } \\
\hline Laki-laki & $21(60)$ \\
\hline Perempuan & $14(40)$ \\
\hline \multicolumn{2}{|c|}{ Usia (rentang 1 bulan -16 tahun) } \\
\hline$<1$ tahun & $25(71,4)$ \\
\hline$\geq 1$ tahun & $10(28,6)$ \\
\hline \multicolumn{2}{|l|}{ Status gizi } \\
\hline Kurang & $14(40)$ \\
\hline Baik & $15(42,9)$ \\
\hline Lebih & $6(17,1)$ \\
\hline \multicolumn{2}{|l|}{ Skor ASA } \\
\hline 1 & $1(2,9)$ \\
\hline 2 & $19(57,1)$ \\
\hline 3 & $15(42,9)$ \\
\hline \multicolumn{2}{|l|}{ Kategori luka operasi } \\
\hline Bersih & $31(88,6)$ \\
\hline Bersih tercemar & $4(12,4)$ \\
\hline Tercemar & 0 \\
\hline Terinfeksi & 0 \\
\hline \multicolumn{2}{|l|}{ Jenis tindakan operasi } \\
\hline Neurosurgery & $18(54,4)$ \\
\hline Abdominosurgery & $14(40)$ \\
\hline Orthopaedic & $3(8,6)$ \\
\hline \multicolumn{2}{|l|}{ Lama operasi (jam) } \\
\hline$\leq 2$ & $22(62,9)$ \\
\hline$>2$ & $13(37,1)$ \\
\hline \multicolumn{2}{|l|}{ RBP } \\
\hline Meningkat & $23(65,7)$ \\
\hline Menurun & $12(34,3)$ \\
\hline \multicolumn{2}{|l|}{ Kortisol } \\
\hline Meningkat & $15(42,9)$ \\
\hline Tidak meningkat & $20(57,1)$ \\
\hline \multicolumn{2}{|l|}{ CRP } \\
\hline Meningkat & $14(40)$ \\
\hline Tidak meningkat & $21(60)$ \\
\hline \multicolumn{2}{|l|}{ Luaran } \\
\hline Sepsis & 0 \\
\hline Tidak sepsis & $35(100)$ \\
\hline \multicolumn{2}{|l|}{ Luaran } \\
\hline Asepsis skor 10-19 & $32(91,4)$ \\
\hline Asepsis skor 20-29 & $2(5,8)$ \\
\hline Asepsis skor 30-39 & $1(2,9)$ \\
\hline Asepsis skor $40-70$ & 0 \\
\hline
\end{tabular}


pascabedah berisiko mendapatkan infeksi luka operasi 4,4 kali dibandingkan subjek dengan kadar RBP yang meningkat $(p=0,26 ;(95 \%$ IK 0,35-54,5). Subjek dengan skor ASA $\geq 3$ berisiko mendapatkan infeksi luka operasi 1,3 kali dibanding subjek dengan skor ASA 1-2, tetapi secara statistik tidak bermakna dengan RO 1,3 ( $\mathrm{p}=0,07 ; 95 \%$ IK 0,97-1,6). Peningkatan kadar CRP pada hari ke-5 pascabedah berisiko terjadinya infeksi luka operasi 3,3 kali, tetapi secara statistik juga tidak didapatkan perbedaan yang bermakna. Tidak didapatkan perbedaan bermakna antara status nutrisi prabedah, peningkatan kadar kortisol, maupun lama operasi terhadap risiko infeksi luka operasi. Semua subjek memiliki luka operasi bersih dan bersih tercemar, sehingga tidak dapat dilakukan analisis bivariat terhadap infeksi luka operasi.

Tabel 2. Kadar RBP, kortisol, dan CRP hari pertama dan kelima pascabedah

\begin{tabular}{lcc}
\hline & Hari ke-1 & Hari ke-5 \\
& Pascabedah & Pascabedah \\
\hline Retinol binding protein $(\mathrm{mg} / \mathrm{L})$ & $20,8 \pm 2,3(6,3-65,3)$ & $27,8 \pm 2,6(2,8-60,3)$ \\
Kortisol $(\mu \mathrm{g} / \mathrm{dL})$ & $23,8 \pm 3,3(0,7-69,5)$ & $17,7 \pm 2,9(0,9-102,3)$ \\
CRP $(\mathrm{mg} / \mathrm{L})$ & $44,1 \pm 8,37(0,31-147,3)$ & $50,7 \pm 12,6(1,0-280,7)$ \\
\hline
\end{tabular}

Rerata \pm SB

Tabel 3. Analisis bivariat usia terhadap infeksi luka operasi

\begin{tabular}{|c|c|c|c|c|c|c|c|}
\hline \multirow{2}{*}{ Faktor risiko } & \multicolumn{2}{|c|}{ Tidak infeksi } & \multicolumn{2}{|c|}{ Infeksi } & \multirow{2}{*}{$\mathrm{p}$} & \multirow{2}{*}{$\mathrm{RO}$} & \multirow{2}{*}{ IK 95\% } \\
\hline & $\mathrm{n}$ & $\%$ & $\mathrm{n}$ & $\%$ & & & \\
\hline \multicolumn{8}{|l|}{ Usia (tahun) } \\
\hline$<1$ & 23 & 71,9 & 2 & 66,7 & 0,64 & 1,2 & $0,1-15,8$ \\
\hline$\geq 1$ & 9 & 28,1 & 1 & 33,3 & & & \\
\hline \multicolumn{8}{|l|}{ Status nutrisi } \\
\hline Kurang & 13 & 40,6 & 1 & 33,3 & 0,59 & - & - \\
\hline Baik & 13 & 40,6 & 2 & 66,7 & & & \\
\hline Lebih & 6 & 18,8 & 0 & 0 & & & \\
\hline \multicolumn{8}{|l|}{ Lama pembedahan (jam) } \\
\hline$>2$ & 20 & 62,5 & 2 & 66,7 & 0,69 & 0,8 & $0,0-10,2$ \\
\hline$\leq 2$ & 12 & 37,5 & 1 & 33,3 & & & \\
\hline \multicolumn{8}{|l|}{ ASA } \\
\hline ASA $1-2$ & 20 & 62,5 & 0 & 0,0 & 0,07 & 1,3 & $0,97-1,6$ \\
\hline ASA 3 & 12 & 37,5 & 3 & 100 & & & \\
\hline \multicolumn{8}{|l|}{ Kategori luka operasi } \\
\hline Bersih dan bersih tercemar & 32 & 100 & 3 & 100 & - & - & - \\
\hline Tercemar dan kotor & 0 & 0,0 & 0 & 0,0 & & & \\
\hline \multicolumn{8}{|l|}{$\mathrm{RBP}$} \\
\hline Menurun & 10 & 31,3 & 2 & 66,7 & 0,26 & 4,4 & $0,35-54,4$ \\
\hline Meningkat & 22 & 68,8 & 1 & 33,3 & & & \\
\hline \multicolumn{8}{|l|}{ Cortisol } \\
\hline Tidak meningkat & 18 & 56,3 & 2 & 66,7 & 0,61 & 0,6 & $0,0-7,8$ \\
\hline Meningkat & 14 & 43,8 & 1 & 33,3 & & & \\
\hline \multicolumn{8}{|l|}{ CRP } \\
\hline Tidak meningkat & 20 & 62,5 & 1 & 33,3 & 0,55 & 3,3 & $0,3-40,8$ \\
\hline Meningkat & 12 & 37,5 & 2 & 66,7 & & & \\
\hline
\end{tabular}

Fisher's Exact Test 


\section{Pembahasan}

Didapatkan penurunan RBP 34,3\% pada hari ke-1 dibandingkan dengan hari ke-5 pascabedah. Hasil tersebut lebih besar dibandingkan dengan penelitian Junqueira $\mathrm{dkk}^{15}$ yang mendapatkan kadar abnormal RBP 20,3\% pada pembedahan elektive. Perbedaan disebabkan karena populasi maupun kriteria penilaian abnormal kadar RBP. Peneliti membandingkan perubahan RBP hari ke-1 dan ke-5 pascabedah, sedangkan Junqueira menggunakan kadar nilai normal sebagai standar penilaian.

Prevalensi infeksi luka operasi adalah 8,6\%. Penelitian Haryanti dkk ${ }^{2}$ di RS Cipto Mangunkusumo didapatkan prevalensi yang lebih kecil (7,2\%). Penelitian di Italia juga didapatkan hasil 5,2\%. ${ }^{16}$ Sebaliknya, penelitian Satyanarayana $\mathrm{dkk}^{17}$ mendapatkan hasil yang lebih besar $(13,7 \%)$. Perbedaan hasil tersebut kemungkinan karena jenis tindakan pembedahan, usia, maupun kriteria yang digunakan dalam menilai infeksi luka operasi. Penelitian Satyanarayana dan penelitian di Italia digunakan subjek dewasa, sedangkan penelitian Haryanti dan penelitian kami menggunakan populasi anak, tetapi penelitian Haryanti hanya menggunakan pasien dengan jenis tindakan pembedahan abdomen. Penelitian kami menggunakan skor ASEPSIS untuk menentukan infeksi luka operasi. Sepsis merupakan salah satu komplikasi infeksi pada pasien pascabedah. Namun, penelitian kami tidak mendapatkan subjek dengan diagnosis sepsis. Haryanti mendapatkan 6 dari 13 subjek dengan infeksi luka operasi mengalami sepsis, bahkan 2 di antara pasien sepsis tersebut meninggal. ${ }^{2}$

Subjek dengan kadar RBP yang menurun pada hari ke-5 pascabedah memiliki risiko 4,4 kali mendapatkan infeksi luka operasi. Hasil penelitian ini hampir sama dengan penelitian Junqueira dkk yang mendapatkan hubungan antara kadar RBP, prealbumin, dan transferin yang rendah dengan komplikasi infeksi. Rasio Odds untuk RBP terhadap komplikasi infeksi penelitian Junqueira dkk pada analisis univariat 4,8 (IK 95\%: 1,2-19,3; $\mathrm{p}=0,03)$, tetapi pada analisis multivariat hanya kadar prealbumin yang berhubungan dengan komplikasi infeksi.

Perlu dilakukan analisis lebih lanjut pengaruh asupan nutrisi terhadap penurunan kadar RBP sehingga dapat dijelaskan RBP sebagai prediktor malnutrisi. Retinol binding protein sangat dipengaruhi oleh respon stres dan sedikit dipengaruhi oleh tunjangan nutrisi. Retinol binding protein sebagaimana halnya dengan prealbumin tidak dipengaruhi oleh usia dan jenis kelamin. Namun, prealbumin lebih sensitif menilai perubahan nutrisi dibandingkan dengan RBP sehingga mungkin prealbumin merupakan indikator nutrisi yang lebih baik. ${ }^{19}$

Usia $<1$ tahun berisiko mendapatkan infeksi luka operasi 1,2 kali dibandingkan subjek dengan usia 1 tahun atau lebih. Namun, tidak didapatkan hubungan antara status nutrisi prabedah dengan kejadian infeksi luka operasi. Hasil tersebut serupa dengan penelitian sebelumnya oleh Haryanti dkk maupun penelitian di Meksiko oleh Porras-Hernandez dkk. ${ }^{2,21}$ Penelitian kami mendapatkan skor ASA, terutama skor 2 dan 3. Semua subjek yang mengalami infeksi luka operasi memiliki skor ASA 3. Pada kategori luka operasi, semua subjek hanya memiliki jenis luka bersih dan bersih tercemar. Keduanya bukan merupakan faktor risiko infeksi. Subjek dengan skor ASA 3 memiliki risiko mendapatkan infeksi luka operasi 1,3 kali dibandingkan subjek yang memiliki skor ASA 1-2.

Berdasarkan indeks risiko Nosocomial Infection national Surveillance Service (NINSS), terdapat 3 faktor yang berhubungan dengan infeksi, yaitu kondisi klinis pasien buruk (skor ASA 3-5), luka operasi terkontaminasi/terinfeksi, dan lama operasi lebih dari 2 jam atau lebih. Risiko infeksi luka operasi meningkat dari 1,5\% menjadi 13\% ketika skor NINSS meningkat dari 0 ke 3. Namun, baik skor ASA maupun lama pembedahan keduanya tidak berhubungan dengan kejadian infeksi luka operasi. Hasil penelitian kami serupa dengan penelitian Haryanti maupun penelitian Porras-hernandez dkk. ${ }^{2,14,20}$ Kadar CRP dan kortisol plasma dapat digunakan untuk menilai keadaan stres metabolik. Kortisol akan meningkat segera setelah pembedahan, dan kadarnya akan kembali normal pada hari ke-2, ke-4, dan ke-7 setelah pembedahan.

Kadar C-reactive protein meningkat 4-6 jam pasca trauma dengan kadar puncaknya 24-48 jam, dan pada hari ke-3 kadarnya kembali ke baseline. Makalah lain menyebutkan penurunan CRP terjadi secara lebih lambat. Pada penelitian kami dapatkan rerata kortisol menurun pada hari ke-5, sedangkan rerata CRP masih lebih tinggi pada hari ke-5 pasca pembedahan. Peningkatan konsentrasi CRP pada pembedahan mengikuti perubahan IL-6. $C$-reactive protein berkorelasi dengan luas dan derajat proses inflamasi. Douraiswami $\mathrm{dkk}^{22}$ mendapatkan peningkatan persisten CRP pada hari ke-4 berkorelasi dengan infeksi pada pasien pascabedah. ${ }^{11}$ Penelitian 
lain mendapatkan durasi pembedahan yang lebih lama dan obesitas berhubungan dengan peningkatan kadar CRP. Kadar CRP yang tinggi berkorelasi dengan penyembuhan fungsional yang lebih lambat pada pasca tindakan hiparthroplasty. ${ }^{23}$ Kami mendapatkan pasien dengan peningkatan CRP memiliki risiko infeksi luka operasi 3,3 kali dibandingkan subjek yang kadar CRP menurun, tetapi secara statistik tidak bermakna sehingga tidak dapat digeneralisasikan untuk populasi umum. Kortisol yang tinggi pada hari ke-5 tidak berhubungan dengan kejadian infeksi luka operasi. Hal tersebut menunjukkan bahwa kenaikan kadar CRP kemungkinan lebih berkaitan dengan keadaan respon stres. ${ }^{11,19}$

Keterbatasan penelitian kami adalah jumlah subjek yang mengalami infeksi hanya 3 dari 35 subjek. Hal tersebut yang mungkin dapat menjelaskan mengapa faktor usia kurang dari 1 tahun, skor ASA, penurunan kadar RBP pada hari ke-5 dan peningkatan kadar CRP pada hari ke-5 memberikan risiko infeksi luka operasi berturut-turut 1,2; 1,3; 4,4 dan 3,3 kali. Meskipun tidak didapatkan perbedaan, terdapat 1 subjek yang mengalami burst abdomen pada penilaian ASEPSIS skor ke-3. Subjek dengan burst abdomen tersebut berusia 6 bulan, dengan diagnosis pascabedah teratoma, skor ASA 3, lama operasi 80 menit, status nutrisi prabedah gizi baik dan jenis luka operasi luka bersih. Kadar RBP hari pertama pascabedah $7,4 \mathrm{mg} / \mathrm{L}$ dan menurun pada hari ke-5 pascabedah menjadi $6,4 \mathrm{mg} / \mathrm{L}$. Kadar CRP mengalami peningkatan dari $98,2 \mathrm{mg} / \mathrm{L}$ pada hari pertama pascabedah menjadi 159,4 pada hari kelima pascabedah. Demikian juga peningkatan kadar kortisol, $14,6 \mu \mathrm{g} / \mathrm{dL}$ pada hari pertama menjadi $24,03 \mu \mathrm{g} /$ dL. Dengan demikian, dari kasus dan hasil penelitian kami, kewaspadaan kita terhadap kemungkinan terjadinya infeksi luka operasi perlu ditingkatkan apabila didapatkan adanya penurunan kadar RBP pada hari kelima pascabedah mayor.

\section{Kesimpulan}

Terdapat $34,3 \%$ subjek yang mengalami malnutrisi berdasarkan penurunan kadar RBP pada hari ke-5 pascabedah. Subjek yang mengalami infeksi luka operasi $8,6 \%$. Tidak didapatkan subjek yang mengalami sepsis. Tidak didapatkan data kategori luka operasi yang berhubungan dengan risiko infeksi luka operasi. Penurunan RBP pada hari ke-5 pascabedah berisiko 4,4 kali mendapatkan infeksi luka operasi, usia $<1$ tahun berisiko 1,2 kali dibanding usia $\geq 1$ tahun, skor ASA $\geq 3$ berisiko 1,3 kali dibandingkan dengan skor ASA 2 atau kurang, peningkatan CRP pada hari ke-5 pascabedah berisiko 3,3 kali, tetapi semuanya tidak terdapat perbedaan bermakna. Lama operasi $>2$ jam dan status gizi prabedah tidak berhubungan dengan terjadinya infeksi luka operasi.

\section{Daftar pustaka}

1. Kahokehr AA, Sammour T, Wang K, Sahakian V, Plank LD, Hill AG. Prevalence of malnutrition on admission to hospital-Acute and elective general surgical patients. Eur J Clin Nutr and Metab 2010;5:e21-5.

2. Haryanti L, Pudjiadi AH, Irfan EKB, Thayeb A, Amir I, Hegar B. Prevalens dan faktor risiko infeksi luka operasi pasca-bedah. Sari Pediatri 2013;15:207-12.

3. Garth AK, Newsome CM, Simmance N, Crowe TC. Nutritional status, nutrition practices and post-operative complications in patients with gastrointestinal cancer. J Hum Nutr Diet 2010;23:393-401.

4. Fuhrman MP, Fada, Charney P, Mueller CM. Hepatic proteins and nutrition assessment. J Am Diet Assoc 2004;104:1258-64.

5. Drescher T, Singler K, Ulrich A, Koller M, Keller U, crain M, Kressig RW. Comparison of two malnutrition risk screening methods (MNA and NRS 2002) and their association with markers of protein malnutrition in geriatric hospitalized patients. Eur J Clin Nutr 2010;64:887-93.

6. Parrish CR. Serum proteins as marker of nutrition: what are we treating? Pract Gastroenterol 2006:46-64.

7. Burton D, Nicholson G, Hall G. Endocrine and metabolic response to surgery. Continuing Education in Critical Care \& Pain 2004;4:144-7.

8. Blebuyk JF, Phil D. The metabolic response to stress: an overview and update. Anesthesiology 1990;73:308-27.

9. Gruys E, Toussaint MJM, Niewold TA, Koopmans SJ. Acute phase reaction and acute phase protein. J Zhejiang Univ Sci 2005;11:1045-56.

10. Arafah BM. Review: Hypothalamic pituitary adrenal function during critical illness: limitations of current assessment methods.J Clin Endocrinol Metab 2006: 91:3725-45.

11. Douraiswami B, Dilip PK, Harish BN, jagdish M. C-reactive protein and interleuikin-6 levels in the early detection of infection after open fractures. J Ortho Surg 
2012;20:381-5.

12. Villet $\mathrm{S}$, Chiolero RL, Bollmann MD. Negative impact of hypocaloric feeding and energy balance on clinical outcome in ICU patients. Clin Nutr 2005;24:502-9.

13. Garth AK, Newsome CM, Simmance N, Crowe TC. Nutritional status, nutrition practices and post-operative complications in patients with gastrointestinal cancer. J Hum Nutr Diet 2010;23:393-401.

14. Ercelo FF, Starling CE, Chianca TC, carniero M. Appicability of the nosocomial infection surveillance system risk index for prediction of surgical site infection: a review. Brazilian J Infect Dis 2007;11:134-41.

15. Junqueria JCS, Soares EC, Filho HRC, Hoehr NF, Magro DO, Ueno M. Nutritional risk factors for postoperative complication in brazilian elderly patients undergoing major elective surgery. Nutrition 2003;19:321-6.

16. Petrosillo N, Drapeau CMJ, Nicastri E, martini L, Ippolito G, Moro ML, Anipio. Surgical site infection in Italian Hospital: a prospective multicenter study. BMC Infect Dis 2008;8:34.

17. Satyanarayana V, Prashanth HV, Bhandare B, Kavyashree AN. Study of surgical site infection in abdominal surgeries. J Clin Diag Res 2011;5:935-9.
18. Petrica A, Brinzeu C, Brinzeu A, Petrica R, Ionac M. Accuracy of surgical wound infection definitions-the first step towards surveillance of surgical site infections. TMJ 2009;59:362-5.

19. Lopez-Hellin J, Baena-Fustegueras JA, Schwartz-Riera S, Garcia-Arumi E. Usefulness of short-lived protein as nutritional indicators surgical patients. Clin Nutr 2002; 21:119-25.

20. Raguso CA, Dupertuis YM, Pichard C.The role of visceral protein in the nutritional assessment of intensive care unit patients. Curr Opin Clin Nutr Metab Care 2003;6:211-6.

21. Porras-Hernandez JD, Villar-Compte D, Cashat-Cruz M, Ordorica-Flores RM, Bracho-Blanchet E, AvilaFigueroa C. Prospective study of surgical site infection in a pediatric hospital in Mexico City. Am J Infect Control 2003;31:302-8.

22. Reinke JM, Sorg H. Wound repair and regeneration. Eur Surg Res 2012;49:35-43.

23. Hall GM, Peerbhoy D, Shenkin A, parker CJ, salmon P. Relationship of the functional recovery after hip arthroplasty to the neuroendocrine and inflammatory responses. Br J Anaest 2001;87:537-42. 